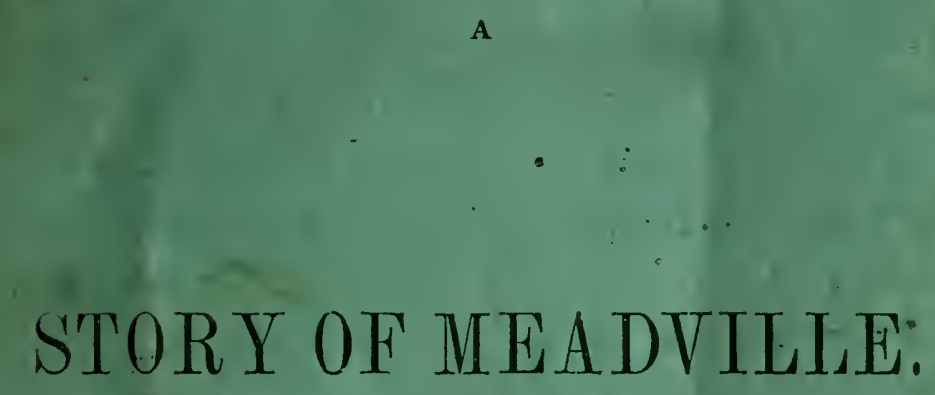





\section{STORY OF MEADVILLE.}

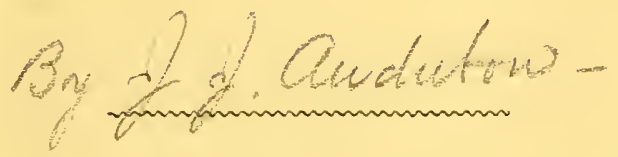

B OS T ON :

1846.

EASTBURN'S PRESS. 
A

\section{STORY OF MEADVILLE,}

FROM JOHN J. AUDUBON, F. R. S.

A U GUS T 28, 1824 .

On a shore of Upper Canada, my money was stolen. The thief, perhaps, imagined it was of little importance to a naturalist. To repine at what could not be helped would have been unmanly. I felt satisfied Providence had relief in store. Seven dollars and a half were left to us, two persons, 1,500 miles from home, at the entrance of Presque-Isle Harbor. A gale prevented our passage of the bar. Providence, on whom I ever relied, aided us. Captain Judd, U. S. N. came to our relief. My drawings were safe; for anything else, I then cared but little. I searched in vain for Captain Judd, gave a dollar to the sailors and went to a humble inn for bread and milk, and to consider how to proceed.

We hired, for five dollars, a cart for our baggage, to Meadville. It rained nearly the whole day. At night, we alighted at our conductor's home. Only the cheerful grandmother was there. As actively as age permitted, she got a blazing fire to dry us, bread and milk enough for several besides us, then showed us into a bed room. 
We told her I would paint her portrait for her children, and went to sleep. We were waked by a light carried by three damsels, who, having ascertained where we lay, blew it out, and got into a bed opposite to our's. In our back woods, one bed room often suffices for a farnily. We did not speak; they probably supposed us to be asleep; we heard them say how delighted they would be to have their portraits, as well as the grandmother's. My heart silently met their desire.

Day dawned, they had dressed themselves in silence and left us before we were awake. We joined the family and were kindly greeted. I made known my intention as to the portraits; the girls disappeared and soon returned in their Sunday elothes. The black ehalk was soon at work, to their great delight; the fumes of the expected breakfast reaching my sensitive nose, I worked with redoubled ardor. The sketches and breakfast were soon finished. I played a few airs on my flageolet, and by ten o'clock we and the cart departed. I shall not forget Maxon Randall and his hospitable family. Arrived at Meadville, our conduetor instantly faced about, put the whip to his nags and bade us adieu.

We had but a hundred and fifty cents. No time was to be lost. Wo entered J. E. Smith's "Traveller's Rest," then took a walk to survey the little village now to be laid under contribution for our support. It seemed dull; but, thanks to Grod, I never despair while rambling to admire His grand and beautiful works. I walked up Main street, examining heads till I saw a Hollander gen. 
tleman in a store, who looked as if he might want a sketch. I begged him to allow me to sit down. This granted, I remained purposely silent till he very soon asked "what is in that port folio?" This sounded well, I opened it. He complimented my drawings of birds and flowers. Showing him a sketch of my Best Friend, I asked if he would like one of himself. He said "yes, and I will exert myself to gain as many more customers as I can." At "the Traveller's Rest," at supper, I was asked to say grace; they thought I was a priest, my hair flowing on my shoulders; I did so fervently.

Next day, I entered the artist's room, by crazy steps of the store-garret; four windows faced each other at right angles; in a corner was a cat nursing, among rags for a paper-mill; hogsheads of oats, Dutch toys on the floor, a large drum, a bassoon, fur caps along the walls, a hammock and rolls of leather. Closing the extra windows with blankets, I procured a painter's light!

A young man sat, to try my skill; his phiz was approved: then the merchant; the room became crowded. In the evening, I joined him in music on the flute and violin. My fellow traveller also had made two sketches. We wrote a page or two in our journals, and went to rest. The next day we spent as yesterday. Our pockets replenished, we walked to Pittsburg in two days.

Fifteen years after, that artist had published his "drawings of birds and flowers :" for each complete set, he received, from at least a hundred and sixty persons, Societies or States, from $\$ 800$ to $\$ 1000$ each. “The little village" is now a considerable town; its two colleges were founded from N. England; one of them asks our help.

April 9 th, 1846. 


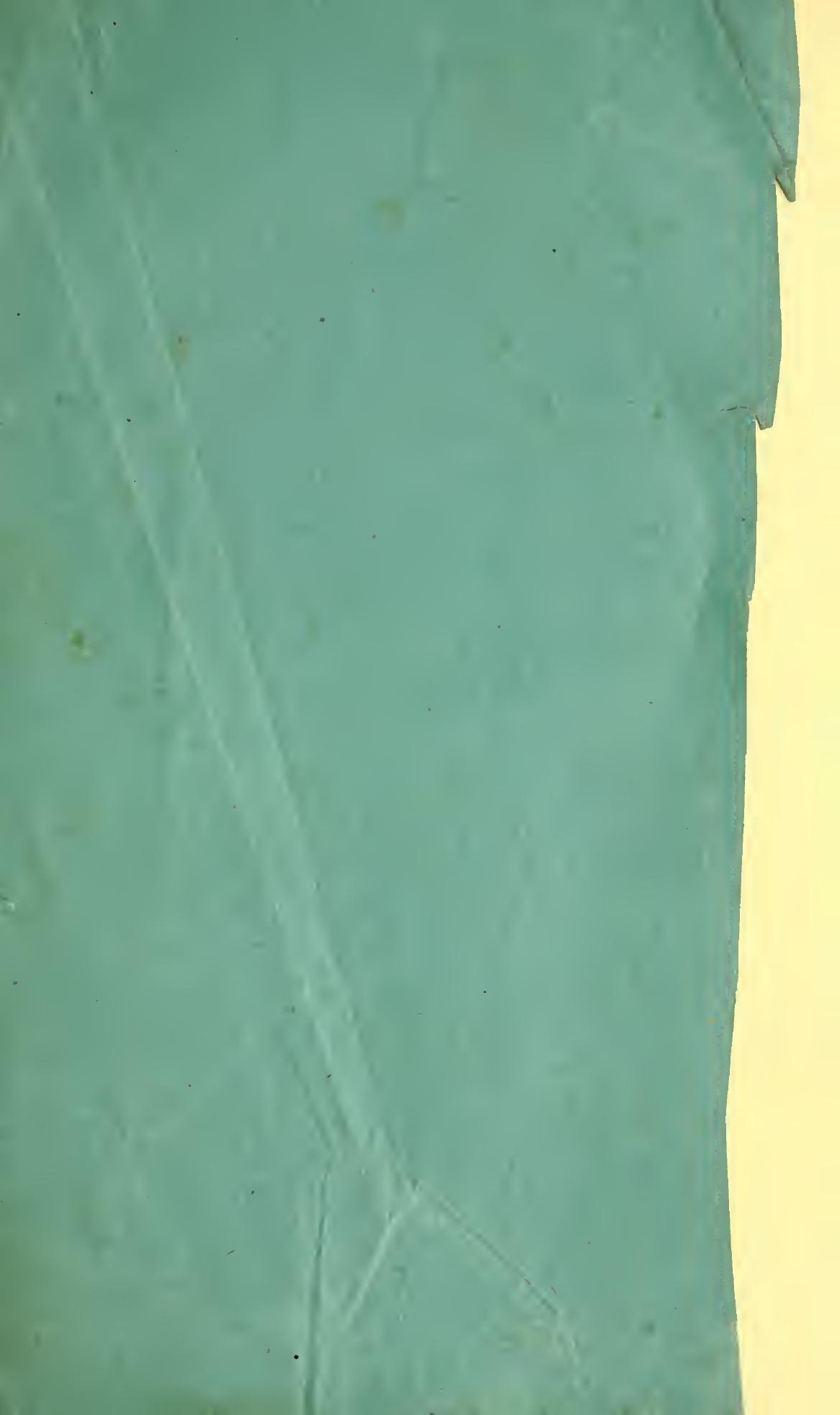




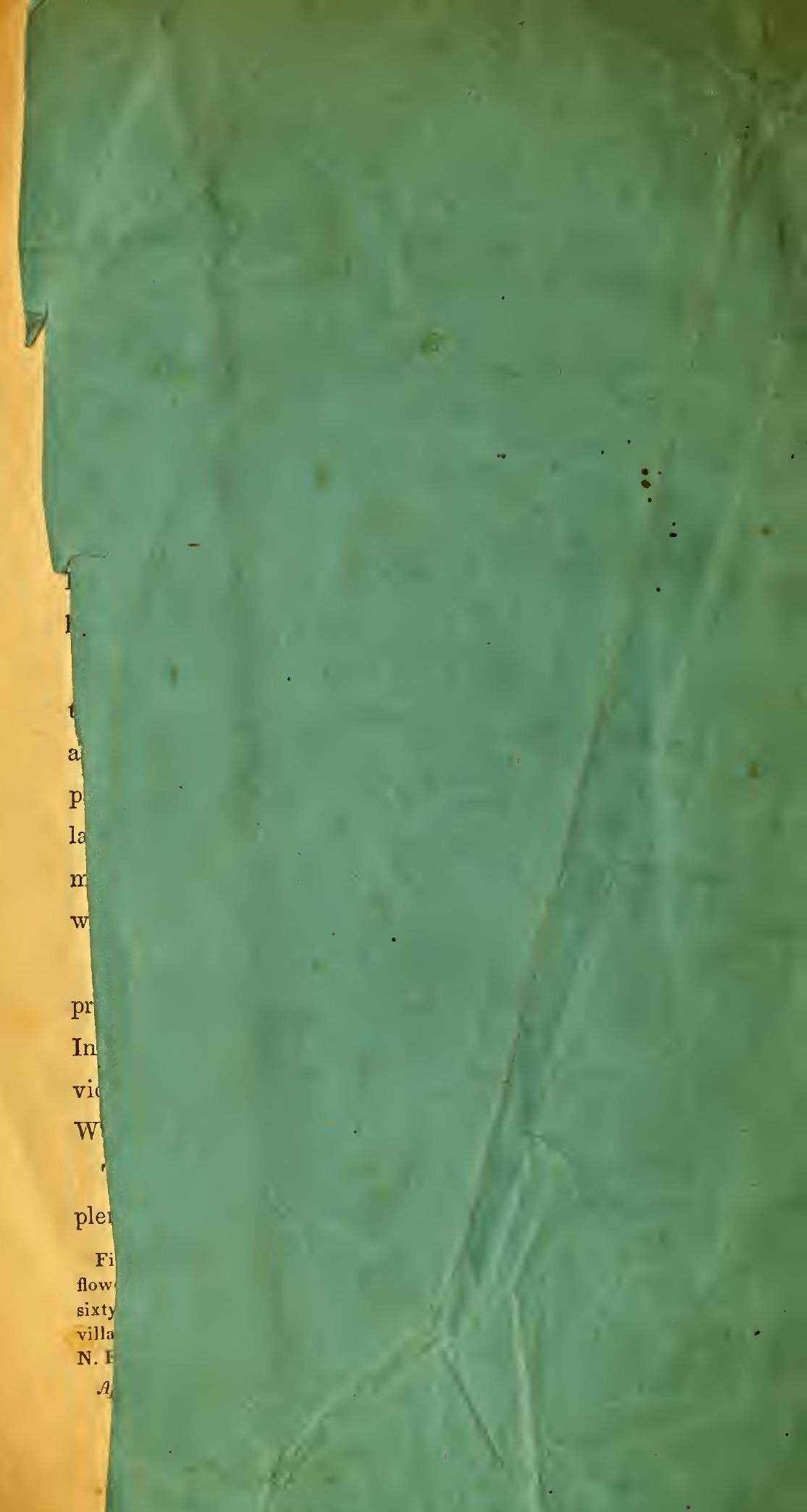

